\title{
Preliminary thoughts on the relevance of the research field of cognition for Practical Theology
}

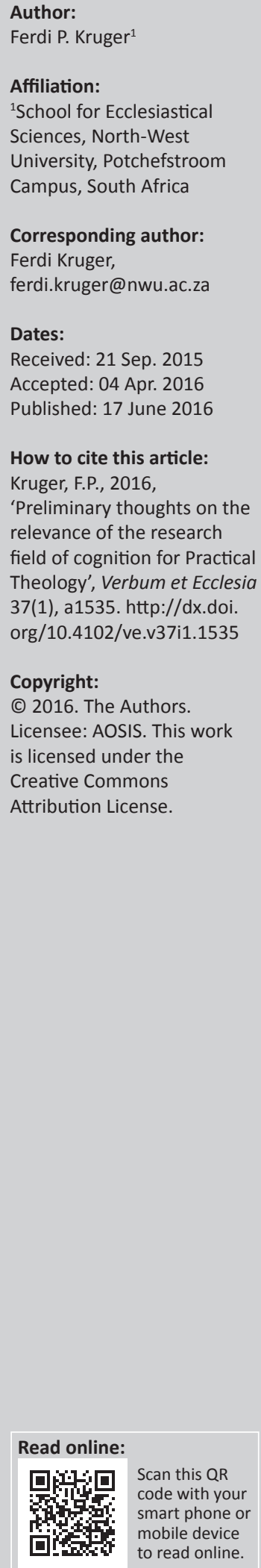

In this research from the vantage point of Practical Theology, the author focusses on the importance and the possible value of the concept of cognition for further research. The philosophical roots of the concepts of knowledge and understanding are highlighted in a qualitative manner by means of a short selection from the insights of philosophers from the era of the Greek Philosophy to the nineteenth century. The insights of Plato, Aristotle, Thomas Aquinas, Descartes and Kant are utilised. The purpose was to indicate the importance of the concepts of knowing and cognition from an early stage. Research from the field of cognitive science also received attention in this research. The purpose of this discussion is to indicate that cognition is not a mere intellectual activity. Cognition is important in the processes of perspective-making and moral choices. Cognitive distortions could possibly endanger people's ability to have the right cognition about people, events and life itself. The concept of phronesis, as the concept that comes the nearest to the essence of cognition, is also investigated from the vantage point of Philippians 2:5 and Romans 12:3. Wisdom thinking is really important in research on the acts of people from a practical theological vantage point. Cognition must be regarded as people's attempt to make sense out what they already know and also out of what they are observing. In the final part of the article, fields for possible further investigation are highlighted in order to make the statement that practical theologians can consider the fact to reclaim the field of investigation on cognition in further research. The importance of cognition for liturgy, homiletics, pastoral care and youth ministry is indicated.

Intradisciplinary and/or interdisciplinary implications: This article is undertaken from a practical theological vantage point in order to highlight the importance of the concept of cognition for further research. In this article a discourse between Practical Theology, Philosophy and Cognitive Psychology is undertaken. Important aspects were indicated and also the importance of the concept of phronesis. The importance of understanding and insight were also indicated. The concept of phronesis was discussed from Philippians 2:5 and Romans 12:3. Finally, practical theological perspectives were offered in which the importance of cognition for the various fields in Practical Theology was indicated.

\section{Introduction}

In scientific analysis there is much data and little action, whereas in everyday thinking there is much action but less data. Action is the main purpose of everyday thinking. (De Bono 1981:37)

It must be acknowledged that everyday thinking has been recently influenced through the functioning of the digital world to such an extent that it transformed thinking about everyday life. Learning processes, cognitive structures and also the gaining of knowledge are deeply affected by the digital environment (Prétot 2015:4). Practical Theology in its focus on acts could benefit from knowledge about the different kinds of communication available to people in order to negotiate the dynamics from theory to life (action). Practical theological research has to do with extensive knowing (cognition) on various levels and therefore the following pivotal aspects regarding knowledge must also be recognised. Practical theological investigation is concerned about the acts of knowledge about, knowing how to be, knowing how to do and knowing how to live (Prétot 2015:5). It is evident that practical theological research is dealing with this complex reality of knowing that also includes the aspect of cognition. The cognitive aspects of human life are important in order for persons to participate meaningfully and in a communicative manner in church and also in society (Barnard 2015:9).

A well-known practical theologian from the Netherlands, Immink also highlighted the fact that people must become aware of the fact that everything that is investigated in Practical Theology is about people and their lives (Immink 2014:179). It has to do with a process of trying to make sense 
of things, life itself and events in people's lives. Recognition of this very fact that communicative acts in church and in life are also touching my life (sense of life) is putting the aspect of cognition on the agenda of practical theological research. Although scholars are mentioning some of the aspects in cognitive development, the need still exists to explore the concept of cognition further in Practical Theology. Cognitive science can be spoken of as a field of research (Peterson 2003:26). Kuhn coined the concept of paradigm to indicate a set of commitments and theories that guides research, set criteria and also provide testable hypothesis (Stanley 2008:257). Paradigms underlie the practice of science and are resistant to change. Persistent anomalies can occur and in the accumulation of the anomalies; old paradigms are replaced by another and more adequate competitors (Peterson 2003:27). In this article the author intends to indicate that practical theological research can benefit from the insights of the new development in cognitive science, because of the fact that cognitive science also has undergone its own paradigm revolutions. Modern cognitive science has expanded to include new domains like research into emotion and also research into thinking processes (Louw \& Louw 2007:23; Peterson 2003:29; Woolfolk 2007:39). Contemporary cognitive science also takes the architecture of the brain much more seriously (Bergh \& Theron 2006:373; Kruger 2016:14; Prétot 2015:14; Watts 2002:79; Woolfolk 2007:42). Within this new focus the importance of the body and the place of environment (social cognition) are also taken seriously.

This research could make a possible contribution to practical theological investigation on topics like inter alia the epistemology for Practical Theology, the methodology in Practical Theology, the rationality or ontology in Practical Theology and also on the topic of what the specific research field of Practical Theology entails. The noun, theology for instance literally means 'thinking about God' (Louw 2015:36). If theology for instance is not dealing in one way or another with the knowledge (cognition) of God or the encounter with God, theology will have difficulty in sustaining the epistemic demand (Louw 2015:37). The process of theologising further takes place within a very unique field of the tension between faith and reason. Practical Theology also reckons, since the onset of Schleiermacher's accentuating of the place and the role of Practical Theology, with the concept of cognition, because it has to do with thinking and understanding of communicative acts. Pieterse (2001:9-11) also underlined the fact that Practical Theology has to with knowledge about God, but also with the process in which people are learning to know God.

Ballard and Pritchard (2006:41) added to this view and reflected on the task of practical theologians in understanding the community of faith and also in helping people to discover answers (the sense) of the praxis of life in order to live faithfully. Bergh and Theron (2006:375) highlighted the fact that people are organising facts in their minds in order to make sense of the world. Buttrick (2005:1171) sets a challenge also for Practical Theology, namely 'the need to explore how the symbolic strength of Christianity for making sense of life and for successfully coping with life can take shape in the church under today's complex socio-cultural conditions'. To the best of the author's knowledge the essence of cognition as an attempt to make sense of life is well known in Practical Theology, although the concept of cognition is quite unfamiliar.

The research problem for this research could be defined in the following way, namely:

- What are the reasons for practical theological research to rediscover the research field of cognition?

- What kind of perspectives could be offered for further utilisation of the concept of cognition within practical theological research?

Browning's (1996:13) description on a research activity ranging from description, to systemising (exploring practical wisdom and understanding), to strategising (practicing strategic Practical Theology) is regarded as suitable as methodology for this article. This investigation will be exploratory of nature and in order to address this research problem, it will be important to consider the historical or philosophical roots of the concept of cognition. Therefore a qualitative literature study will be undertaken. Data sources are therefore determined by the information richness of information available and the purpose is to enrich understanding of the phenomenon. This qualitative research has the intention to explain the possible lack of insight in utilising the concept of phronesis within practical theological investigation and therefore the investigation is further aimed at the verification of the idea that the concept of phronesis can be influential in further investigation. A process of analysis and interpretation will further be executed mainly from literature in the fields of philosophy and Cognitive Psychology. The concept of phronesis will also receive attention in order to provide a normative anchor for the concept of cognition. In the last phase of this research perspectives will be drawn regarding the fields of homiletics, liturgy, pastoral care and also youth ministry in order to highlight the importance of the concept of cognition for Practical Theology.

\section{Descriptive research on the notion of cognition}

Osmer (2008:32) in connection with Browning regarded the descriptive activity in the following manner: 'Practical theology begins with episodes, situations, or contexts that call for interpretation. Therefore, practical theology invites scholars/students to interpret the texts of contemporary lives and practice'. The descriptive task seeks to answer the question: what is going on in the research field? It has been argued that the essence of cognition is known in Practical Theology but the concept of cognition is quite unfamiliar. In the limited literature research (from the field of Practical Theology) undertaken, that reckons with research in different countries over the last 15 years, the following aspects are explored that will underline the statement above. For the 
author, it is evident that the fingerprints of the principle of cognition are already present in research, although the concept is not yet coined. Further research within the field of cognition could possibly enrich further research within Practical Theology.

In this subsection a few examples will be provided. Van der Rijst (2015:225) for instance indicated in her research that the role of post-modernism within a European context can never be underestimated. Face-to-face relationships are replaced inter alia by Facebook relationships. The impact of the consumption culture is influencing people's understanding of local congregations and also the acts that are being investigated in Practical Theology. Therefore it could be deducted that the traditional way of thinking and living of believers are also experiencing constant pressure. Borden (2012:161) underlines the attitude of preachers that do not realise that there is a growing church for people who are not there yet. It can happen that preaching with the negative attitude towards people in society can become a hindrance to mission in the marketplace. Preachers must carefully consider what they are going to say and also how they are going to say it (understanding is required). Although ministers are trained there is yet so much to learn and to understand in a problematic praxis. Through their preaching, preachers have to open the vision for what should happen and what should be understood in society and in the community. Purposeful liturgy and purposeful preaching are matters of dynamic interchange between text and context, and therefore, contextualisation always link to daily life (Ott \& Strauss 2010:284). The expression of 'purposeful' is bringing the concept of knowledge and the ability to think about possibilities in order to do that, to the surface of attention. The connection between liturgy, liturgy of life and liturgy of the streets is announced and this mere fact requires understanding of powerful contextualised worship services.

Brouwer (2004:81-85) wrote about 'koinonia met daklozen als diaconaal leerproces'. The act of 'diaconaat' is communication in which somethings are given but are also received. This entails that believers have to be exposed to the world of other people in order to create an encounter. This encounter can help people to become more sensitive for the needs of other people, a real liturgical challenge. It must be mentioned that people's emotional experiences are influenced, not only by their concrete situation, but also by their cognitive observation, appraisal or interpretation of that particular situation (Kruger 2016:17). Although Brouwer is not utilising the concept of cognition, the essence of cognition and understanding is present in his contribution. Pieterse (2009:253) expresses his concern about the attitude of preachers within a South African context with specific reference to their reluctance to deliver their sermons in such a way that the Word can perform true transformation. Pieterse is concerned about the understanding of preachers and their responsibility to contribute to true transformation. He identifies a possible reason for this, namely doubt about
God's presence during the worship service and during the act of sermon delivery. Clarity or knowledge about the main assumptions is needed.

Eswine (2008) offers an interesting contribution to this topic by stating:

We shall never understand the spiritual movements of our own or of any other generation, unless we see that God's controversy with idols and idolatries is the main controversy of the world. (p. 218)

Eswine is also interested in the fact that people must understand what is going on in life and especially the functioning of powers behind reality of life. The author named above is interested in the understanding and deeper insight of people in order to make sense of what is happening on the depth level of their lives.

Hermelink (2007:29-32), from a German perspective, is concerned by the way preaching can help people to reflect on a multitude of voices that are heard in sermons, questions about life, doubts and also arguments. The challenge for Hermelink (2007:31) is to confront the language of facts with a language of promise. This kind of preaching needs a certain kind of knowledge. Stott (2007:123) also describes the task of preachers as a double act of listening. Preachers have to listen to the Word of God with humility. They should also listen to the voices of the modern world. When they are listening to the Word they do it in order to believe and obey the Word. When they are listening to the world they are doing it in order to understand the world and with the intention to proclaim the Word sensitively. Knowledge or deeper insight is also needed in order to do that. Brueggemann (2010:17) did research on a changing situation, because of the fact that old modes of church absolutes are no longer trusted. The mistrust of conventional authority is a result of a growing suspicion about the linkage between knowledge and authority. The issues about absolute knowledge and absolutism that can easily become a dominating knowledge are therefore on the agenda of churches worldwide. Long (2005:11-13), on his turn, focussed on the changing trends in preaching. The relationship between Bible, congregation, preacher and sermon are bounded in a system of interrelationships and this is fascinating for Long. These changing interrelationships also acquire knowledge (cognition). Troeger (2007:116) is also interested in the new standards in evaluating effective preachers. He indicated that the imaginative construction of the world has become more complex, leaving believers with less certainty about inherited language and whether it is really adequate in expressing the reality. Although Troeger did not mention the concept of cognition, it is evident that knowledge (cognition) is needed.

In this limited literature research about investigation in different countries, it became evident that the issue of cognition is currently relevant in practical theological research, but the concept and the essence of cognition has not yet been investigated in its full bed. 


\section{Understanding the concept of cognition within its philosophical and psychological roots}

In this article the author recognises the interdisciplinary approach of the social sciences as well as the intradisciplinary approach (Cartledge 2003:15; Pieterse 2001:13).

\section{Interdisciplinary perspectives on cognition from the field of Philosophy}

Warburton (2005:40) indicated that philosophy has the purpose to question and to understand the common ideas that all people are using every day without thinking about them. The questions regarding what is the meaning of life and what is knowledge are important aspects that are distinctive from the insights of ancient philosophers in particular (Hetherington 2003:39). The issues regarding meaningful and meaningless are evident from the literature study on certain philosophers. The exposition of the insights of Plato, Aristotle, Thomas Aquinas, Descartes and Kant will hopefully highlight the importance of knowledge for practical theological epistemology. It is important to note that the philosophers named above are mere examples of people who have elaborated on this concept of insight and meaningful. In this sense of the word they are examples of a bigger stream of thinkers in history. The description of the philosophers' contributions could be helpful to indicate the important role of thinking (cognition) from an early period, but could also be helpful to warn against the danger of thought and knowledge that is regarded as a mere intellectual practice.

\section{Plato's view on knowledge (cognition)}

Chambliss (1989:163) indicated that Plato firmly believed that the uniqueness of humankind, the humanity of human beings, arises in thought. Knowledge is virtue and begins with sensory observations and is extended through reason (Allen 1985:19). Plato continued and said that knowledge is made perfect by faith, which transforms knowledge into meaning and purpose (Chambliss 1989:164). Thought is both necessary and inadequate. It is necessary because it has to open the way to faith, but it is also inadequate because deeper insights are felt as well as understood (Hetherington 2003:39). Human thought reaches beyond the senses to grasp the eternal and changeless (Allen 1985:30). In Plato's epistemology he draws something of a division between what is sensible and what can be grasped by the intellect only (Allen 1985:47).

In order to highlight this he described three images, namely the sun, the divided line and the cave (Sosa 2008:37). In this process the importance of eyes that must be able to see (observe) and the need of light (sun) is accentuated. The Form of the Good gives the objects of the intellect their truth and to the person who grasps truth, the power of knowledge (Allen 1985:47). In Plato's second analogy of divided lines, a line is first divided to represent the visible world (appearances or phenomena) and the intelligible world (reality). Each segment is also divided that represents degrees of clarity (Allen 1985:50). In one of Plato's dialogues, the Republic, a philosophy of people who are unknowingly imprisoned, is told (Hetherington 2003:43). The people are chained in the cave without any experience of the world outside. The problem is that they are not aware of the lack of knowledge. The people inside the cave even have social interaction with each other. Anyone who wants to enter the cave and tell the people about reality will experience disbelief from the people. Their happiness lies in their ignorance, while understanding of the world is lacking (Furley 2007:2; Hetherington 2003:43). Plato tried to warn people about the danger of misleading themselves and their conception about reality. He tried to underline the fact that there is something (cognition) beyond everyday life.

Plato's description on human caves is important in practical theological reflection. To be unaware of the outside world is nothing else to lose touch with reality. The challenge in practical theological investigation is really to become aware of the world and not only of the reality of God's Word. People must learn to know (understand) more about the world they are living in without withdrawing into caves. Without understanding (cognition) of ourselves, the Word of God and also the world we are living in, people tend to misunderstand the meaning of life. This is according to Plato also the difference between a meaningful and meaningless life (Hetherington 2003:44). In Plato's description the essence of the process of knowing and also of the gathering of information are coming to the surface.

Plato used the concept of phren (Greek word) to denote something physical but also to denote the inner person. The phronesis of the soul means receptivity (Bromiley 1985:1277). Phronesis and sofia are interchangeable. Therefore phronesis is the right state of the intellect and also the source of virtue. To educate somebody is to admonish them towards phronesis and truth (Bromiley 1985:1277). The problem with Plato's thinking was the fact that he firmly believed that nobody can both believe and know the one truth, something of I do not believe it, but I know it (Hetherington 2003:135). Knowledge is something that one's reason is giving to him or her. Plato in this way opened the way for mere intellectual thinking about cognition. In his epistemological thinking there was a definite abyss between knowing and believing.

\section{Aristotle's view on knowledge (cognition)}

According to Aristotle, everyone by nature desires to know (Furley 2007:3). The greatest pleasure comes from knowledge of whatever in nature and is eternal (Furley 2007:3). Allen (1985:117) indicated that logic was not a science or body of knowledge for Aristotle. Aristotle divided sciences into theoretical sciences, practical sciences and productive sciences. Logic was the preparation for the study of these sciences. Logic teaches people to reason rightly so as to gain knowledge (Allen 1985:117). Aristotle was concerned about the question: what is the best possible way in which a person 
can live? His discussion about this topic became influential in history (Hetherington 2003:49). The question has to do with what the point of life is and also the issue about whether there must be a point in life. He was concerned about a certain form of happiness which he called eudaimonia (Warburton 2005:175). Hetherington (2003:50) also indicated that Aristotle was concerned about the supreme good there could be in living as a person. To have eudaimonia is not the same as subjective experience of pleasure but rather has to with the flourishing of life (Hetherington 2003:49). Flourishing of life has to with acting according to virtue and intellect (Sosa 2008:84). No animal is capable of this practical and intellectual wisdom. Furley (2007:118) referred to Aristotle's view on happiness and indicated that the human soul can be divided into rational and also non-rational parts. The rational part is concerned with intellectual virtues that can be called phronesis or practical wisdom (Furley 2007:119). The virtue of thought comes mostly from teaching and in some cases it is acquired very early. Teaching also steers people in learning the correct habits of virtue (Furley 2007:119). The ability to comprehend (phronesis) only belongs to a few and is denoting the idea of moral insight or knowledge that leads to a virtuous life.

Aristotle distinguished the theory of what he called hylemorphism (matter and form). The two principles of matter and form are something that everything consists of (Van der Walt 1981:44). Matter is the bodily things in Aristotle's thinking and form is the soul. The notion of purpose of man is, according to Aristotle, thinking something to think of and man's ability to express his rationality, the rational soul (Sosa 2008:62). The nous of humans activates the form of man, his rational soul (Van der Walt 1981:44). Thinking itself became the originator and creator in Aristotle's thinking. Therefore Aristotle's epistemology was merely empiricistic (Sosa 2008:317).

According to Aristotle people have scientific understanding of something when they believe they know the cause (aitia) of something. Aristotle begins with terms, then analyses the syllogism, which is an arrangement of several propositions (form of rational arguments). Aristotle's view on science was that of a deductive science, from the general to the particular (Allen 1985:118). People take premises that are known to be true and then draw conclusions that are also known to be true, because it emanates from the premises (Sosa 2008:10). The theory of syllogistic reasoning is, according to Aristotle, concerned with the relation between premises and the conclusion (syllogism). In his epistemology he reckoned with indemonstrable starting points (Warburton 2005:175). The thinking of Aristotle has influenced many philosophers and it could also be fair to say that it also dominated history for a long period of time (Allen 1985:160).

Although much critical voices can be added to Aristotle's contribution and to the fact that thinking was merely his god, it must be stated that his insights on thinking and ethics are something practical theologians can elaborate on. The flourishing of human life is another aspect that is important in practical theological epistemology. To be moral and to have the knowledge about living in a moral manner is also a very important aspect that can be learned from Aristotle's thinking. It became clear from the above discussion that people's knowledge about life really matters. Knowledge is not just about intellectual things but also about the empirical reality.

\section{Thomas Aquinas' view on cognition (13th century)}

Thomas Aquinas sought to harmonise Aristotle with Christian doctrine (Allen 1985:152). Thomas distinguished between two types of knowledge, namely knowledge (cognition) about God and knowledge of the cosmos (Van der Walt 1981:144). Faith also has the characteristic of knowing. Thomas Aquinas, in distinction to Plato and Aristotle, highlighted the important fact that faith is no uncertain matter. To keep reckoning with cognition in practical theological research is also to have cognisance about the fact that faith also has to do with the dimensions of understanding and knowing. Thomas Aquinas also highlighted the existence of two kinds of cognitive activities, namely a speculative cognition and also a practical cognition (Van der Walt 1981:144). In the speculative cognition thought is playing a major role while the human will is playing a predominant role in practical cognition. Thinking has to with knowledge and the will with actions. Thomas regarded knowledge of the universal things as important (Warburton 2005:555). Knowledge is guided by the senses of people because knowledge is gathered through human senses. Science is not about facts according to Thomas. Science has to do with universal causes and must prove why things are like they are (Van der Walt 1981:144). Thomas Aquinas thinking has to do with knowledge of the universal things. It could also be fair to say that knowledge on the causality of things was important in his thinking. Faith and knowledge are functions of the human intellect (Van der Walt 1981:146). Faith has the function of a bridge between the processes of opinions (opinion), faith (fides) and knowing (scientia). Faith is more solid that opinions, but not so secure as knowledge (Van der Walt 1981:146). The human thought is preparing the way for faith, something that Thomas described as the preambula fidei. Within the preambula fidei is the rational thought of the existence of God (Van der Walt 1981:147). Thomas Aquinas was concerned about the fides quarens intellectum (reasonable faith). Although Thomas did not keep reckoning with pneumatology, it is still important to note his perspective on the reasonable faith, the process in which people are trying to make sense about faith.

\section{Descartes' view on cognition (16th and 17th centuries)}

Allen (1985:171) believes that modern philosophy starts with Descartes. Descartes was concerned about epistemology and also about the grounds for certainty. Descartes believed that all knowledge is infallible (Hetherington 2003:137). Mathematics was for Descartes the ideal of all knowledge (Furley 2007:123). His method of arriving at certainty is to begin by doubting everything which can be doubted until the 
researcher finds which facts cannot be doubted (Allen 1985:172). In this instance, Descartes wanted to free people from their dependence on sense perception and prejudices. He was sure and certain about one thing, namely cogito ergo sum (I think, therefore I am) (Allen 1985:175). Descartes brought to the foreground that human's minds also matter (Furley 2007:122). People know via reason. Descartes, though, did not indicate that people's minds are really as strong and powerful as he indicated. Cartesian epistemology consists of two projects, namely identifying criteria by which we ought to regulate acceptance and rejection of beliefs in order to determine what is said to know according those criteria (Sosa 2008:538). The big question in Descartes mind was what kind of propositions are worthy of belief? The concept of justification is still also the dominant concept in modern epistemology. The concept of knowing and of cognition was a dominant thought, also in the thinking of Descartes.

\section{Kant's view on cognition (18th - 19th centuries)}

Kant was concerned about the issue on how we can know the world around us (Hetherington 2003:138). Kant is famous for his 'Critique of Pure Reason' (Hetherington 2003:138). Kant was like Plato, also concerned with how do we know of the world around us? (cf. the description of Plato). Kant's view has an interesting side, namely that we know of the world around us through experience (Furley 2007:124). Experience is much more than sensations, though, because sensations also need interpretation (Hetherington 2003:138). People possess a prior ability to interpret sensations. Experience can tell people that a thing is so, but not that it must be so (Allen 1985:205). Kant distinguished between phenomena (objects as they appear) and noumena (objects as they are in themselves). Only the phenomena could be known by people (Hetherington 2003:139). Nobody can know what the world is like in itself. Knowledge or cognition of the world relies on our senses interacting with the world (Hetherington 2003:139). Kant highlighted the perspective that people are experiencing things about other people and life. Experiences must be interpreted (cognition). It is evident that the essence of cognition is also a main line in Kant's reasoning.

\section{Concluding systemising perspectives on the philosophical insights}

In the discussion on the views of the philosophers, certain concepts were identified, namely understanding, meaning, knowledge, the tension between know and believe, knowledge, the role of human experience and the living of a moral life. Although much can be said in order to criticise the philosophers, it is evident that knowledge and the understanding of people and life were important also during the times of the philosophers. The essence of cognition, although it was not coined by the philosophers, is eminent from this discussion. The tension between knowing and believing that the philosophers experienced is also relevant in modern thinking. In the positive sense of the word two important issues were raised in this subsection, namely the knowledge of what is happening in daily life and also the process of knowing or living of a moral life. Thinking and trying to make sense (cognition) of what you are thinking is important for people. Practical Theology can link up with these two important issues in research on cognition. On the other hand the description on the philosophical roots of the process of knowing was also a danger sign for any reflection on the epistemology in Practical Theology, namely that research could be wrongly seen as merely an intellectual activity. Therefore the next subsection could be helpful in avoiding the danger of mere intellectualism.

\section{Understanding the importance of cognition: Perspectives from Cognitive Psychology}

One of the primary tasks of theologians over the years has been to explicate how theological claims (epistemology) are rationally defensible. The issue at stake is why anyone would believe that (Peterson 2003:15). In the previous section it is indicated that the 'that (content of cognition)' at stake is understood differently over the years. Aristotle for example mentioned the unmoved mover, Aquinas spoke about the soul as form of the body, whereas Descartes spoke about a non-extended thinking thing. In order for theology to be scientific and relevant, it must also make claims about the world (reality) and in order to do that, rational (cognitive) modes of thought are needed (Peterson 2003:17). But how are the cognitive sciences significant for theology? The concept of cognition can be helpful as a lens for Practical Theology. A lens clarifies (Peterson 2003:21). In this sense of the word the lens of cognition does not dictate practical theological investigation, but provides insights into the research field of knowing processes. In order to address this issue a discourse with the field of Cognitive Psychology will be undertaken. Watts (2002:33) for instance described the interest in some circles in social sciences to determine whether there is some kind of God like-ness in wanting people to use their own minds to understand mind itself. Seybold (2007:80) also indicated that psychologists (neuropsychologists) are even interested in the brain's involvement in religious experiences. The function of the neuro lobe, for instance, in religious and mystical experiences as kind of an electrically unstable part of the brain which can relate to things other than real sensory input is also something neuropsychologists elaborated on. This highlights the fact that the concept of cognition is worth further research and also to determine to which extent Practical Theology can make use of this concept of cognition as a possible lens.

\section{What is cognition?}

In the opinion of Weiten (1992:270) cognition refers to the mental processes involved in acquiring knowledge. Cognition has to do with thinking. Baron and Byrne (1994:108) highlighted on their turn the need of people to think about and increase their understanding of people and events. They also indicated the fact that when people are experiencing positive feelings (affect), difficult tasks seem easier to deal with. On the contrary, people tend to cope with great difficulty to tasks and problems when they are experiencing negative feelings (Baron \& Byrne 1994:115). People's emotional experience is influenced not only by their concrete 
situation, but also by their cognitive observation, appraisal or interpretation of that particular situation (Eysenck \& Keane 2010:571-572).

Swartz and De La Rey (2004:215) referred to the famous metaphor of Piaget that described cognition as interiorised action. Therefore thinking involves thinking by doing and to put patterns of action together. Bergh and Theron (2006:373) described cognition as the processes of knowing. The following four aspects are important, namely:

- The process of perception by which events are detected and interpreted by individuals. In this process new ideas and behaviours are acquired.

- The concept of memory as manner in how knowledge is retained.

- The aspects of thinking, reasoning, problem-saving and decision-making as ways in using knowledge.

- Knowledge is represented in the form of episodic memory (visual or auditory memories) and also semantic memory which refers to the abstract representation of the meaning of things (Bergh \& Theron 2006:373).

It is important to note that people in their relationship with the environment like to be active, to explore, to manipulate, to control, to create and to accomplish things (Louw \& Louw 2007:23). Fiske (2004:123) although offered a different angle on this topic by indicating that cognition also constitutes the process by which people think about and try to make sense of other people, themselves and also their social situation. Eysenck and Keane (2010:35) referred to the role of visual perception for everyday which allows people to see and observe people with whom they are interacting. People rely on visual perception to be accurate to ensure their own safety. According to Eysenck and Keane (2010:36) the functioning of visual perceptions has to do with the functioning of people's senses (people see, they hear, they taste, they feel). Louw and Edwards (1998:149) rightfully indicated that people's observation of other people is not just a biological matter. All people have something that can be called a perceptual disposition. People's observation of things and other people are influenced by a certain kind of framework (orientation framework). People are exposed to learning processes in which they are constantly receiving information data about their environment and about people, but in this learning process often forget about orientation frameworks based on perceptual dispositions.

The danger also exists that the observation (the utilisation of senses) of other people could be wrong (Fiske 2004:121). Therefore the role and functioning of cognition is really important, because of the fact that people continuously tend to form opinions about other people and also consider the fact if other people are making sense to them (Baron \& Byrne 1994:108). It is important to realise that the process of knowing is not just an element of personality but it is the entire personality (Bergh \& Theron 2006:374). People are active gatherers of information relevant to make decisions. Information from the environment comes in through the senses and is processed or coded for storage in a systematic arrangement for later use. Later on it is decoded and combined with other available information in order to guide action (Bergh \& Theron 2006:375). Without acknowledging the concept of cognition as lens Practical Theology could fall short in its epistemology and in its praxis.

\section{Cognitive distortions endangered perspective-making}

In their attempt to make sense of people, things, and also the social environment, people can make a floater. Fiske (2004:123-127) highlighted the following aspects that influence the acts of people:

- People often try to cut corners when trying to make sense of other people which is called the functioning of cognitive misers. That entails that people, instead of frequently thinking about other people, are making use of dimensions or habitual categories.

- People's (social) cognition must be accurate enough to guide them through their everyday interactions. The other side of the coin is also true, namely that people's cognitions must also be flexible enough to change with changing contexts and circumstances.

Louw and Edwards (1998:548-549) on their turn accentuated the functioning of cognitive distortions.

The following types of cognitive distortions could be distinguished, namely:

- Overgeneralisation. In this kind of distortion people tend to think of other people in a generic way. In the case of cultural and ecclesiastical differences people often think that other people are their enemies or opponents.

- Arbitrary conclusions. People tend to make conclusions without the full picture of knowledge and insight in other people's lives.

- Selective abstraction. People tend to focus on a small part of reality while they are ignoring other important facts.

- All-or-nothing-thinking. People tend to think that people are making sense to them or they do not.

What is the reason for the functioning and existing of cognitive distortions? One of the major reasons for this is misguided schemes (Fiske 2004:143 and also Barker \& Angepoulo 2010:67). The problem with this kind of scheme is that it is been created during the early stages of childhood. These automatic thoughts about other people could be so wrong that it have a negative impact on social interaction between people and also between people from different cultures (Barker \& Angepoulo 2010:68). A schema is a cognitive structure containing the attributes of a concept or type of stimulus and the relationships among the attributes (Fiske 2004:143). Schemas are helping persons to organise and anticipate the data they are experiencing. New information is understood by reference to the old, familiar schemas and expectations. Mitchell (2008:19) underlined the fact that every human experience is in interaction with a specific person, place or thing. Abstract ideas may flit through the rational processes, but the well-remembered experience 
of the whole person (body, mind and spirit) always begins with sense reported data (Mitchell 2008:19). Human experiences are recalled through the memory as images or pictures. The mind senses what is happening through eyes, ears, nose, tongue and touch. The chain effect of cognitive distortions is even more concerning when considering the fact that it also influences people's ability to make or create perspectives of what they are receiving through their senses (Louw \& Louw 2007:305). The ability of perspective-making has to do with the ability to view life from the perspective of other people. Within the field of Practical Theology the communicative acts that are investigated are relying on good and healthy cognition. People are seeing, hearing, smelling, touching and feeling things or acts in their lives. People are trying their best to make sense of this and try their best to give meaning to what they are experiencing (cognition), but the danger exists that their cognitions could go wrong. The ability of perspective-making is really important in practical theological thinking. The focus of Practical Theology has indeed to do with the process in which practical theologians and believers are trying to make sense about acts, people and events.

\section{Cognition and moral development}

In studies on moral development it is also evident that scholars are linking up with the subject of cognition (thinking, understanding, trying to make sense) and moral values. It was also a distinct line in the subsection on the philosophical roots of the concept of cognition. To live a moral life and to develop theories in Practical Theology in order to enable people to live in a moral manner requires knowledge about people, circumstances and reality. It also requires a definite attempt to articulate theories in such a manner that it will make sense to people. It must be sensible.

Louw and Louw (2007:340-342) highlighted the fact that cognitive science is also interested in moral development of people and underlined the following important aspects regarding the relationship between cognition and moral development. They referred to Kohlberg's theory of what he called a cognitive perspective on moral development. According to the authors the following aspects are important:

- Moral reasoning is taking place on three levels, namely the pre-conventional, conventional and post-conventional levels. These levels are correlating with the levels of cognitive development. It is important to note that moral evaluation is not primarily a specific moral choice but rather a form of reasoning that is used to justify a certain answer. It has to do with logic. Moral reasoning is interrelated with cognitive abilities. It must be stated that this opinion of Kohlberg can also become one-sided. It must rather be said that cognitive abilities are only part of the ingredients of the total ability in making moral choices.

- The pre-conventional level is achieved during childhood. Teaching and learning plays a very important role. During this stage children are also developing certain attitudes and schemas regarding the church, society and people. The importance of modelling during this phase could never be underestimated.
- During the phase of conventional morality, conformity to social classes and expectations of other people (family, church and nation) are something people want to conform to. People are judging other's behaviour. During this stage, two stadia could be distinguished, namely morality of mutual interpersonal expectations and also moral behaviour that is regarded as something other people must approve. People do not want to be disapproved of by other people during this stage. The second stage during this phase has to do with the morality of social systems and also with conscience orientation. People's responsibilities and their respect for authority become important during this stage. Practical theological research within the field of youth ministry for instance has much to offer to people who are facing the effects of peer pressure. Insight in the cognitive dynamics is although needed.

- During the post-conventional phase as the highest level of moral development, moral reasoning becomes something people accept out of their own. Norms and values are internalised regardless of the opinions of other people. During this phase two stadia could be distinguished, namely the ability to distinguish between right and wrong and morality on universal ethical principles. It is clear that this stage of moral development is needed within a South African context with numerous challenges regarding immorality, corruption, violence and social problems. Wisdom (phronesis) and true understanding of principles are needed in order to address all the various phenomena.

In this discussion it became clear that people are trying to make sense of their social lives, moral reasoning and also of other people. People are trying to justify their views and opinions on the ground of their own cognition and understanding of life. They are trying to find justified answers in order to help them with moral decisions. In their attempt to try and make sense of life there is also the danger of distortions. The process of trying to make sense (cognition) and also to make moral choices could go wrong because of cognitive distortions. It is important to act in all the different spheres of life and in order to do this, knowledge (grounded cognition) is needed in order to promote perspective-making. In this process moral decisions are required from people in South Africa's society regarding moral decline and societal issues. Therefore a brief discussion on the concept of phronesis is needed.

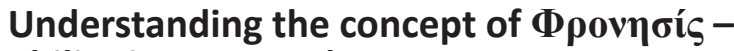 Philippians 2:5 and Romans 12:2}

In the beginning it was stated that the methodological insights of Browning will be utilised. In Browning's visualisation of practical theological investigation a definite dynamic is evident. This dynamic movement moves from description, to systemising (exploring practical wisdom and understanding) and then to the aim of strategising. In this section the idea of systemising will be addressed in order to highlight the importance of the concept of phronesis. In the 
section on the philosophical roots of the concept of cognition,

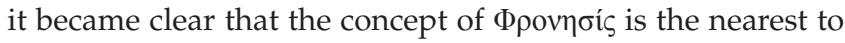
the understanding of philosophers of what cognition entails. Therefore the author now wants to highlight only two passages from Scripture in order to provide normative perspectives on this issue. This section will help in the delineation of the concept of phronesis that is regarded as pivotal in practical theological investigation.

The hymn in Philippians 2:6-11 is connected to the paranetic section, Philippians 2:1-4 by means of Philippians 2:5 (Smit 1995:180). The following words are evident from Philippians

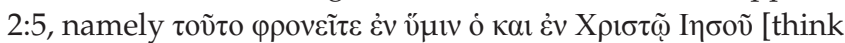
about that what [mind you have in Christ Jesus]. The question is what kind of verb must be assumed in the last part of this sentence. The formula 'in Christ Jesus' is important because that provides the indication that verse 5 must be understood as demand to have the same attitude (mind) as people that are in Jesus Christ (Smit 1995:182). Louw and

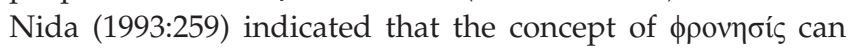
denote to have attitude, to hold a view, thoughtful planning or

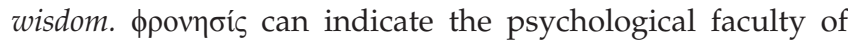
thoughtful planning, often with the implication of being wise and provident in a way of thinking (Louw \& Nida 1993:325).

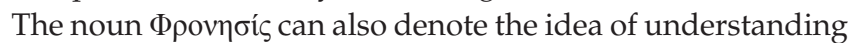
resulting from insight and understanding (Louw \& Nida I 1993:384). The noun Фpovnбís means thought, thinking or reason (Bromiley 1985:1277). In Philippians 2:5 the idea is more the like mind of Christ believers must have. The humble mind of Jesus Christ is the kind of attitude that believers must follow (Manser 2010:2136). The wisdom of phronesis is therefore the driving force behind the actions of religious communities (Louw 2015:62). The attitude of self-renunciation according to the mind or attitude of Christ must be evident in Christ's followers (Müller 1977:39). Brown (1986:616)

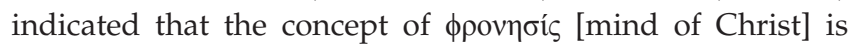
denoting the idea of discernment and judicious insight. The

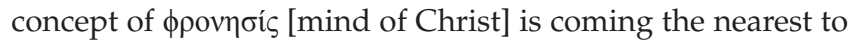
the Old Testament concept of wisdom (Brown 1986:620). The concept is denoting a mental attitude, insight or mentality. In the typical Old Testament way of thinking it has also relevance for the idea of the right understanding of God and life.

In Romans 12:3 it is evident that the command is given,

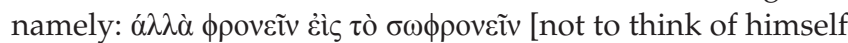
more highly than he ought to think]. It is also striking that the interrelationship between life and thought is indicated when the verb фpovew is used in New Testament (Brown 1986:617). The verb think denotes a movement of the will and not merely an activity of the intellect. It is both interest and decision at the same time and in this process the work of the Holy Spirit must not be underplayed (Rasnake 2005:141). The apostle Paul is using a method of utilising a metaphor in order to help the believers in the congregation to understand their functioning and also their own self-understanding of thinking soberly (Du Toit 2004:193). The metaphor is used in order to indicate God's purpose for his body (Rasnake 2005:141). The suitable knowledge for believers is to have cognition or understanding of their unique place in the body.
Wisdom in the body of Christ entails that every member must recognise the fact that they must be humble regarding their unique place and functioning within the body of Christ (Rasnake 2005:143). In Romans 12:3 the kind of thinking that is suitable for believers is described. Believers are exhorted to think with sober judgement according to the measure of faith. They must think according to their new life in Christ. Thinking about this new life (Romans 12:1) will direct their thinking aright and keep them within proper limits (Brown 1986:618). This will also emanates in a life in which they are saved from pride. The danger of cherishing proud thoughts that are based on higher things which can make people proud is evident in these words. Therefore Paul is using the concept of to be of the same mind up to six times in his letters (Brown 1986:618). The believer's new standing in Christ Jesus both creates and demands a new mentality which comes to concrete expression in the unity of the church (Bromiley 1985:1279).

Louw (2015:64) therefore indicates that the concept of

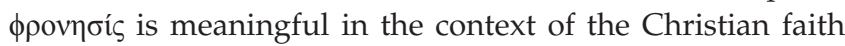
that is dealing with the question about phronesis, namely wisdom as the driving force behind the actions of religious communities. When this search for wisdom is connected to the intention of God's will for human life (the mind of Christ), Practical Theology deals with the praxis of God and his involvement or engagement with the trajectories of human lives.

\section{Conclusions on the concept of cognition (phronesis)}

- The concept of phronesis could possibly be regarded as the concept that describes the meaning of the concept of cognition in the most suitable manner.

- Phronesis (cognition) is not a mere intellectual concept. Phronesis is dealing with the understanding of the mind of Christ (to be his followers), the insight on what is right for daily life, what is the driving force behind decisions, sober judgement according the living faith and the quest for wisdom in church and society.

- Phronesis (cognition) is dealing with the cognitive (thoughts), affective (feelings or will) and also conative (acts and behaviour) aspects of life, although these aspects were not discussed due to limited space.

\section{Practicing strategic Practical Theology}

Up to this stage the article dealt with systemising perspectives from the fields of Philosophy and Cognitive Sciences. The author also described the concept of phronesis, a concept that was evident in the discussion about the philosophical roots of cognition. According to the methodology described in the introduction, the interaction of the elements must be casted into a section on the strategic elements and therefore the intention at this stage is to indicate the value of the concept of cognition (phronesis or wisdom) for Practical Theology. The following aspects regarding the reason why the concept of 
cognition is regarded as important in reclaiming the research field of cognition within Practical Theology will now be highlighted.

\section{The concept of cognition and the epistemology of Practical Theology}

The issue about practical theological epistemology is much more comprehensive than only one subsection of any article can elaborate on. Therefore only one aspect, arising from the discussion earlier in this article regarding epistemology will be highlighted, namely: is knowledge really valuable or is truth the appropriate goal in practical theological epistemology? The issue at stake is why practical theologians should value knowledge if peoplealready have understanding and what should be the use of knowledge about phenomena (Kvanvig 2008:493). From the discussion on the philosophical roots on the concept of cognition it became clear that knowledge has importance above true belief. Descartes for instance indicated that knowledge is not open to doubt and cannot be undermined by further learning, whereas true belief can be.

Louw (2015:65) accentuated the following aspects, namely: Practical Theology is more than phenomenology. It needs description, but in terms of a practical theological ecclesiology and a ministerial hermeneutics there is a normative dimension as well. Practical Theology is about the praxis of the ecclesia as related to the praxis of God within cultural contexts and communities of faith. The discipline cannot bypass the existential realities of life. As a science it needs critical reflection and also rational knowledge. Language, communication, action, hope, creative imagination and the visual dimension of life inevitably play a role in Practical Theology. However, the discipline cannot bypass and ignore the perspective of the Christian faith. In this regard the method of critical and mutual correlation is paramount. Browning (1996:105) calls this the visional dimension of practical moral thinking.

The concept of cognition that is not just an intellectual concept is worth further research. It must be said that not only rational knowledge is needed but also knowledge about wisdom for daily life. Practical theological research could possibly be enriched by research on knowledge, assertion and understanding. The concept of phronesis (cognition) is not just about mere intellectual knowledge but it is also about the importance of knowledge for faith in order to act responsible.

\section{The concept of cognition within a new emergent practice and the challenge for practical theological investigation}

The concepts of understanding, explanation and application are important. Gadamer and Ricoeur for example both referred to the process of application that depends on thorough understanding (Pieterse 2001:86). Practical Theology also requires a certain kind of understanding of the essence of things in order for believers to participate orderly. Without cognisance of the importance of understanding (hermeneutics) practical theological investigation will only become a science that operates on the surface of the existence of people. Understanding (cognition) is needed in order to function on the depth level of existence. People are constantly trying to make sense of what they are experiencing. Browning (1996:35) indicated the importance of understanding and underlined the idea that present realities for instance shape the way people are interpreting the past. The reverse is also true. Existing situations in daily life are colouring people's understanding and thinking (Nullens 2015:22). This very fact enriches the importance of reflection on cultural diversity. Stott (1999:28) connected with this and pleaded for a double listening action by Christians with a view to the execution of their calling in this world and the seeking for grace to discover how the gospel relates to it. The acts that are investigated in practical theological research are also exposed to a certain culture. Herrington, Greech and Taylor (2003:30) described this as the wired togetherness of people. Graham (2002:39) therefore pleaded for creative envisioning within Practical Theology because of the fact that cognitive changes are evident in culture.

Tickle (2008:36-38) did extensive research on the new global emergence-culture and underlined the fact that religion is often in turmoil because of the fact that it has social meaning for people. She referred to the fact that religion is a cable of meaning that keeps humans connected within certain cultures. Tickle (2008:16) also highlighted the fact that this cable of meaning (religion) is currently experiencing an emergence. Tickle (2008:17) described it as the hold of a giant rummage sale. From a historical viewpoint it happens every five hundred years. To address this culture-transition needs insight and understanding (practical wisdom). According to Tickle (2012:181) the church is currently experiencing the fifth tide or tsunami-transition and the impact of this emergence is currently evident in the critical voices and needs people are expressing. People are thinking differently on aspects like inter alia preaching, liturgy, pastoral care and the communion of believers. People even start to think differently on the aspect of religion within society. It is evident that scholars are increasingly emphasising the importance that people should learn (cognition) to care for society. Stott (2007:69) for instance indicated that people have to show to people in society how the Word of God changes their own lives and that the message of the Word is not contradicted by a lifestyle that is not consistent to the message of the Word. The aspects of living religion and the amazement for the Word of God are currently receiving attention in practical theological research. Kruger (2016:1) for example described the importance of social cognition because people are trying to make sense of the actions of other. Immink (2014:178) also indicated that a connection between the Word of God and the reality of people's lives should take place.

The author intends to indicate that the various fields within Practical Theology should consider the fact to reclaim the 
concept of phronesis (cognition) in order to address challenges. The winds of change require insight and understanding. Four examples on how practical theological research could possibly link up with the idea of cognition are now provided.

\section{Cognition and liturgy}

The issue about liturgical formation and the way in which people are conducting worship services has to reckon with the concept of cognition. People should be able to understand what and why they are doing what they are doing in order to take liturgy to daily life and to the streets (liturgy of life and liturgy of the streets). In order to do this people (ministers and believers) have to know how to act. How people are learning and what are the most suitable ways of learning, are also burning issues that require phronesis. Furthermore, the process of cognition is also playing a major role when people of different cultures are meeting each other in worship services and in the manner in which they are participating in worship services.

\section{Cognition and homiletics}

To preach is to speak in good faith about something that really matters to people who attempt to listen or participate in good faith (Deeg 2013:45). People are listening to sermons in order to recognise God's voice (the Good Shepherd's voice). People are listening to sermons in order to hear something beyond daily routines and rationalities (Döhling 2013:84). Wisdom (cognition) for daily life is needed and from the perspective of the world it can also be called relevance. How can hearers be helped to convey sermons to daily life? What kind of sermon delivery is the most suitable one? What kind of messages are the most suitable in persuading people to change their lives and their attitudes? If preaching has the intention to change people's lives, the functioning and effects of cognition within this process should also be underlined. Is it possible that the preacher's and the listener's cognition about each other could influence each other negatively? Within homiletical research the concept of cognition could be helpful in addressing all these issues.

\section{Cognition and pastoral care}

Pastoral care as the encounter of the Gospel with people's lives could be described as a life-long learning process (Louw 1993:55). In this process people are learning more about God (theological learning), but they also learn about themselves (anthropology). This is happening through the sense of faith. Cognition and the event of knowing are a few of the fundamental aspects pastoral care is dealing with. Research on the functioning of cognition could offer new horizons for pastors.

\section{Cognition and youth ministry}

It has often been said that faith from the social viewpoint is also relational (Barnard 2015:9). Children and young people are learning on a daily basis from their Christian networks (including their families), but also from other networks, like the internet and social media. To participate in these networks requires cognition and knowledge. Certain learning impulses and cognitive information are very important. The issue about appropriate information that is needed in order to help young people to become active members of the local congregations (body) is also an aspect that is worth further research. Young people need knowledge about God and also about realities of life (Barnard 2015:10).

\section{Conclusion}

In this article it is indicated that research on cognition could enrich practical theological research. From a philosophical vantage point, but also from the angle of Cognitive Psychology, it was evident that the concept of thinking, understanding and cognition are part and parcel of human life. Practical Theology is interested in knowledge about, knowing how to be, knowing how to do and knowing how to live. Therefore the concept of cognition or phronesis (practical wisdom) is something scholars should take note of. Further research and reflection on the role and the functioning of cognition within Practical Theology is needed. Knowledge about knowing how to be, knowing how to do and knowing how to live, as important focal areas in Practical Theology, are aspects that can benefit from thorough research on cognition.

\section{Acknowledgements Competing interests}

The author declares that he has no financial or personal relationships which may have inappropriately influenced him in writing this article.

\section{References}

Allen, D., 1985, Philosophy for understanding theology, John Knox Press, London. Ballard, P. \& Pritchard, J., 2006, Practical theology in action, Ashford, London.

Barker, R. \& Angelopulo, G., 2010, Integrated organisational communication, Juta, Cape Town.

Barnard, M., 2015, 'Liturgical formation in the network culture', paper presented at the Societas Liturgica, Quebec, Canada, 15th August.

Baron, R.A. \& Byrne, D., 1994, Social Psychology, Allyn \& Bycan, Quebec, USA.

Berg, Z. \& Theron, A., 2006, Psychology in the work context, Oxford University Press, Cape Town.

Borden, P., 2012, 'Leading and preaching', in J. Piper, G. Macdonald, S. Chapman, B. Wilkerson, H. Robinson, J. Arthurs, et al. (eds.), Inspirational preaching, pp. 155-163, Hendrikson Publishers, Grand rapids, Massachusetts.

Bromiley, G.W., 1985, 'Phronesis', in Theological Dictionary of the New Testament, pp. 1275-1278, Eerdmans, Grand Rapids, Ml.

Brouwer, R., 2004, 'Preken in context over de homiletische situatie', in M. Barnard, F. Borger, K. Bregman, R. Brouwer, G. van Ek, G. Immink, et al. (reds.), Als een leerling leren preken, pp. 21-35, Uitgeverij Boekencentrum, Zoetermeer.

Brown, C., 1986, 'Phronesis', in L. Coenen, E. Beyreuther \& H. Bietenhard (eds.), The New International Dictionary of the New Testament Theology II, pp. 616-620, Zondervan, Grand Rapids, MI.

Browning, D.S., 1996, A fundamental practical theology, Fortress Press, Minneapolis, MN.

Brueggemann, W., 2010, The word militant: Preaching a decentering word, Fortress, Minneapolis, MN.

Buttrick, D.G., 2005, 'A reader on preaching', in D. Day, J.A. Astley \& L.J. Francis (eds.), On preaching a parable: The problem of homiletic method, pp. 166-175, Ashgate, Burlington, VT.

Cartledge, M.J., 2003, Practical theology: Charismatic and empirical perspectives, Paternoster, London. 
Chambliss, R., 1989, Social thought, Irvington Publishers, New York.

\section{De Bono, E., 1981, Practical thinking, Penguin Books, New York.}

Deeg, A., 2013, 'Viva vox evangelii-reforming preaching', in J. Hermelink \& A. Deeg (eds.), Preaching God's wisdom, pp. 43-54, Evangelische Verlaganstalt, Leipzig.

Döhling, JD., 2013, 'Viva vox evangelii-reforming preaching', J. Hermelink \& A. Deeg (eds.), He who wants to hear God talking, shall read the Holy Writ, pp. 83-103, Evangelische Verlaganstalt, Leipzig.

Du Toit, A., 2004, Romeine: Hartklop van die evangelie. Beleef God se genade, CTP Drukker, Parrow.

Eswine, Z., 2008, Preaching to a post-everything world, Baker Books, Grand Rapids, MI. Eysenck, M.W. \& Keane, M.T., 2010, Cognitive Psychology, Psychology Press, New York. Fiske, S.T., 2004, Social beings: A core motives approach to Social Psychology, Wiley, Princeton.

Furley, D., 2007, From Aristotle to Augustine, Routledge, New York.

Graham, E.L., 2002, Transforming practice: Pastoral theology in an age of uncertainty, Wipf \& Stock Publishers, Oregon.

Hansen, D., 2004, 'Who's listening out there?', in H. Robinson, R. Chappel, D. Sunukijian \& S.M. Gibson (eds.), Preaching to a shifting culture, pp. 129-147, Baker Books, Grand Rapids, MI.

Hermelink, J., 2007, 'The theological understanding of preaching hope', in C. Vos, L.L. Hogan \& J.H. Cilliers (eds.), Preaching as a language of hope, pp. 29-59, Uitgeverij Boekencentrum, Zoetermeer. (Studia Homiletica 6)

Herrington, J., Greech, R.R. \& Taylor, T., 2003, The leader's journey: Accepting the call to personal and congregational transformation, Jossey Bass, San Francisco, CA.

Hetherington, S., 2003, Reality, knowledge, philosophy, Edinburgh Press, Edinburgh.

Immink, F.G., 2014. The touch of the sacred. The practice, theology and tradition of Christian worship, Eerdmans, Grand Rapids, MI.

Kruger, F.P., 2016, 'n Praktiese-teologiese ondersoek na prediking en die effek van sosiale kognisie in die handeling van kontek-stualisering', In die Skriflig 50(1), Art. \#2006, 11 pages. http://dx.doi. org/10.4102/ids.v50i1.2006

Kvanvig, J.I., 2008, 'Epistemology: An anthology', in E. Sosa, J. Kim, J. Fantl \& M Mcgrath (eds.), Why should inquiring minds want to know? Meno problems and epistemological axiology, pp. 492-507, Blackwell, Singapore.

Long, T.G., 2005, The witness of preaching, Westminster John Knox, Louisville, KY.

Louw, D. \& Edwards, D., 1998, Sielkunde: 'n Inleiding vir studente in Suider-Afrika, Heinemann Continued Education, Sandton.

Louw, D. \& Louw, A., 2007. Die ontwikkeling van die kind en die adolossent, $\mathrm{ABC}$ Drukkers, Bloemfontein.

Louw, D.J., 1993, Pastoraat as ontmoeting: Ontwerp van vir 'n baissteorie, antropologie, metode en terapie, RGN Uitgewery, Pretoria.

Louw, D.J., 2015, Academic theology: Between sapientia (wisdom) and scientia (science). Theory formation in Practical Theology, University of Stellenbosch, Stellenbosch.

Louw, J.P. \& Nida, E.A., 1993, Greek English lexicon of the New Testament (I), United Bible Studies, New York.

Manser, M.H., 2010, Matthew, Zondervan, Michigan. (The New Matthew Henry Commentary).
Mitchell, H.H., 2008, Celebration and experience in preaching, Abingdon Press, Nashville, TN.

Müller, J.A.C.J., 1977, Die brief aan die Fillipense, N.G Kerk Uitgewers, Kaapstad. Nullens, P., 2015, Zorgen voor een eigenwijze kudde, Boekencentrum, Zoetermeer. Osmer, R., 2008, Practical theology: An introduction, Eerdmans, Grand Rapids, MI.

Ott, C. \& Strauss, S.J., 2010, Encountering theology of mission, Baker House, Grand Rapids, MI.

Peterson, G.R., 2003, Minding God: Theology and the cognitive sciences, Fortress, Minneapolis, MN

Pieterse, H.J.C., 2001, Prediking in 'n konteks van armoede, UNISA, Pretoria.

Pieterse, H.J.C., 2009, 'Deelname van gemeentelede aan die prediking: n Herbesinning', Praktiese Teologie in Suid-Afrika 23(1), 139-154.

Prétot, P., 2015, 'Benchmarks for a history of liturgical formation', paper presented at the Societas Liturgica, Quebec, Canada, 11th August.

Rasnake, E., 2005, Romeine, Christelike Uitgewersmaatskappy, Vereeniging.

Swartz, L. \& De La Rey, C., 2004, Introduction to Psychology, University Press, Oxford.

Seybold, K.S., 2007, Explorations in neuroscience, psychology and religion, Ashgate, Oxford, Pennsylvania.

Smit, A., 1995, 'Nuut gedink oor leierskap in gemeentes', in C. Burger, J. Hendriks, M. Van der Merwe \& A. Smit, (reds.), Gemeente en bediening. Nuut gedink oor leierskap in gemeentes. Die begeleiding van 'n christelike gemeenskap, pp. 16-36, Lux Verbi, Kaapstad.

Sosa, E., 2008, 'Epistemology: An anthology', in E. Sosa, J. Kim, J. Fantl \& M. Mcgrath (eds.), Knowledge and practical interest, pp. 721-742, Blackwell, Singapore.

Stanley, J., 2008, 'Epistemology: An anthology', in E. Sosa, J. Kim, J. Fantl \& M. Mcgrath (eds.), The place of truth in epistemology, pp. 477-491, Blackwell, Singapore Stott, J., 1999, New issues facing Christians today, Zondervan, Grand Rapids, MI.

Stott, J., 2007, The living Church. Convictions of a lifelong pastor, Inter Varsity Press, Nottingham.

Tickle, P., 2008, The great emergence: How Christianity is changing and why, Baker Books, Grand Rapids, MI

Tickle, P., 2012, Emergence Christianity, Baker Books, Grand Rapids, MI.

Troeger, T.H., 2007, 'Seeing visions and dreaming dreams: The imaginative power of preaching hope', in C. Vos, L.L. Hogan \& J.H. Cilliers (eds.), Preaching as a language of hope, pp. 73-80, Uitgeverij Boekencentrum, Zoetermeer. (Studia Homiletica 6).

Van der Rijst, R., 2015, De uitzaaiing van het Woord. Homiletiek in het spoor van Derrida, Knöller-Müller, Otterlo.

Van der Walt, B.J., 1981, Van Athene na Genéve, Pro Rege, Potchefstroom.

Warburton, N., 2005, Philosophy: Basic readings, Routledge, London.

Watts, F., 2002, Theology and psychology, Ashgate, Burlington, VT.

Weiten, W., 1992, Psychology: Themes and variations, Brooks \& Cole, California.

Wood, S.E. \& Wood, E.G., 1999, The world of psychology, Allyn \& Bacon, Boston, MA.

Woolfolk, A., 2007, Educational psychology, Pearson, Boston, MA. 